\title{
Uncovering the Special Mathematical Work of Teaching
}

\author{
Deborah Loewenberg Ball
}

\begin{abstract}
Helping young people develop mathematical skills, ways of thinking, and identities, and supporting classrooms as equitable communities of practice, entails for teachers a specialized set of instructional skills specific to the domain. This paper argues that, although progress has been made in understanding "mathematical knowledge for teaching," more study is needed to understand interactive mathematical work of teaching and to orient teachers' professional education to this dynamic and performative mathematical fluency and activity.
\end{abstract}

\section{Introduction}

A basic problem for both policy and practice is to identify what teachers need to know in order to teach mathematics well. Although it is obvious that teaching depends on knowing the subject, unanswered questions about the specific knowledge needed to teach mathematics have preoccupied teacher educators and researchers alike. This paper traces the effort to frame and investigate this problem and to develop useful ways to understand and solve it.

\section{A Common Question: "How Much" Mathematics Do Teachers Need to Know?}

The quest to identify and quantify teachers' mathematical knowledge dates back several decades. There is widespread agreement that teachers must know mathematics in order to teach it. This has been taken for granted. Although many

D.L. Ball $(\bowtie)$

University of Michigan, Ann Arbor, Michigan, USA

e-mail: dball@umich.edu 
researchers, policymakers, and teacher educators expressed concern that teachers typically did not know enough mathematics, less consensus has been reached about how much mathematics teachers needed in order to teach well. This has led to claims, reports, and recommendations focused on the number-or sometimes the content — of courses that teachers should take. Many arguments have centered on how much mathematics teachers should know, others on what is most important to know. Although it might seem straightforward, the question of the mathematics teachers need to know has been not at all simple to answer convincingly.

Although the basic assumption seemed obvious - after all, how can one teach something that one does not know well? - numerous studies failed to show that the amount of mathematics that teachers study clearly or consistently predicts their students' learning. "Amount" tended to be measured in terms of attainment, either by completing a concentration in mathematics at the postsecondary level or by taking a certain number of university-level courses. This was an unsettling discovery in some ways, but it led to a new question: what mathematical skill and insight does teaching actually require? Clearly, it requires mathematics, but if it is not the amount of knowledge, then what is it about the mathematics that matters for good teaching?

These questions were far from new. Over a century ago, Dewey (1902) had flagged the special way of thinking about content through the mind of the child. But common worries about teachers' knowledge had nonetheless persisted, without satisfactory ways to articulate exactly the nature of this special way of thinking. Shulman and his colleagues (1986, 1987) aptly named it "pedagogical content knowledge," which significantly advanced the field. Researchers around the world probed the mathematical knowledge needed for teaching and began to find better answers (e.g., Adler \& Davis, 2006; Ball, Thames, \& Phelps, 2008; Baumert et al., 2010; Blömeke et al., 2015; Bruckmaier, Krauss, Blum, \& Leiss, 2016; Carrillo, Climent, Contreras, \& Muñoz-Catalán, 2013; Herbst \& Kosko, 2014; Hill, Schilling, \& Ball, 2004; Kaiser, Busse, Hoth, König, \& Blömeke, 2015; Knievel, Lindmeier, \& Heinze, 2015; McCrory, Floden, Ferrini-Mundy, Reckase, \& Senk, 2012; Rowland, Huckstep, \& Thwaites, 2005; Saderholm, Ronau, Brown, \& Collins, 2010; Senk et al., 2012; Tatto et al., 2008; Tchoshanov, 2011). Studies have ranged from investigations of what teachers (and preservice teachers) know (or lack) (e.g., Ball, 1990; Baumert et al., 2010; Hill, 2007; Rowland et al., 2005; Thompson, 1984); what teachers learn from interventions, or other opportunities to learn mathematics (e.g., Borko et al., 1992; Hiebert, Morris, \& Glass, 2003); to articulating positions about what teachers should know (e.g., Conference Board of Mathematical Sciences, 2001, 2012; McCrory et al., 2012; Silverman \& Thompson, 2008). Many efforts were made to get closer to the use of mathematics in teaching (e.g., Adler \& Rhonda, 2015; Ball et al., 2008; Bruckmaier et al., 2016; Goffney,

\footnotetext{
${ }^{1}$ A thorough review of relevant studies that investigate relationships between teachers' mathematical knowledge and students' learning and teaching quality can be found in National Mathematics Advisory Panel (2008).
} 
2010, 2014; Goffney \& Hoover, 2017; Herbst \& Chazan, 2015; Hoover, Mosvold, \& Fauskanger, 2014; Hill, 2011; Hill \& Ball, 2004; Hill, Rowan, \& Ball, 2005; Rowland, 2013; Sfard, 2007; Sherin, Jacobs, \& Phillipp, 2011; Thompson, Carlson, \& Silverman, 2007).

Some scholars developed measures of this special kind of knowledge (e.g., Bruckmaier et al., 2016; Herbst \& Kosko, 2014; Hill, Ball, \& Schilling, 2008; Hill et al., 2004). It is beyond the scope of this paper to represent or discuss the many projects that sought to understand in more nuanced ways the kind of mathematical skill and insight teaching actually requires. Important to note, however, is that scholars shifted from asking "what mathematics do teachers need to know" to "how is mathematics used in teaching" (Ball, Lubienski, \& Mewborn, 2001).

Alongside this quest to uncover how mathematics is used in teaching, a strong emphasis on measurement was emerging in the broader political and scholarly environments. Funders encouraged assessment of impact and outcomes, and researchers responded by developing tests to evaluate teaching and studying how teaching relates to learning. Projects built a host of new tools, items, and tasks of all different kinds. The emphasis on measurement certainly helped to advance the effort to understand teacher knowledge; it also shifted the trajectory and impeded some aspects of the unanswered questions about the mathematical knowledge needed for teaching.

First consider briefly the advances. Across all of these efforts, researchers have made a great deal of progress in learning that there are special kinds of knowing of mathematics that matter for good teaching. We understand that it is not as simple as how many courses someone takes. We also developed better ways to study what teachers learn from teacher education and professional development. The tools and measures researchers built during this measurement period have helped us better understand what teachers learn. These tools hold potential to offer more precise information about what teachers might have learned than simply asking teachers what they learned, or whether they found the professional development useful or enjoyable. We now have better ways of assessing what teachers learn from professional education.

The emphasis on measurement, however, drew focus away from fundamental questions about the role of teachers' mathematical knowledge in teaching and its importance for students' learning. Although many researchers viewed teaching from sociocultural perspectives, asking about what teachers do with students in classrooms, the development of assessment tools was based in more individualistic and cognitivist perspectives. ${ }^{2}$ Many started out trying to understand the mathematics in teaching, but more often ended up measuring individual cognitive capabilities of teachers instead. For many scholars, this invisible but significant shift in lens meant that the questions that were being asked and answered drifted away from the fundamental problems about mathematics knowledge and teaching.

\footnotetext{
${ }^{2}$ I am grateful to Anna Sfard for discussions and insights about this phenomenon (e.g., Sfard, 2007).
} 
Research was not capturing the dynamic of what teachers actually do when they listen to students, make decisions about what to say next, move around the room, and decide on the next example. Scholars were studying classrooms and analyzing discourse, tasks, and interactions, but were not unpacking what is involved for the teacher in doing those things. The measurement work also led scholars to break up teaching into compartments, which is not the way teaching is enacted in practice. For example, work focused on mathematics was often separated from a focus on equity. However, in teaching, concerns for equity — who has the floor, who is being recognized, whose ideas are being valued - are entangled in the construction of mathematics, of what is asked and emphasized, and of what it means to do or be good at math.

The advances in assessment and measurement were important. As a scientific enterprise, the field had developed better microscopes. Because they had better tools, researchers were able to get closer to many micro-level aspects of teachers, including their values, beliefs, and reasoning; their competencies; and their mathematical, pedagogical, and professional content knowledge. These tools also took us inside classrooms and enabled us to see, study, and "measure" teaching - as researchers. However, we were not inside of what it takes to do teaching as a teacher. Capturing the patterns of student participation does not explain what goes on inside the practices of calling on, supporting, and distributing students' talk, or of constructing and distributing different kinds of talk turns, and to whom about what aspect of the mathematics. Describing how students are positioned by the teacher or their peers and how that is shaped by identities and perceptions does not open a window on to what it takes, in moment-to-moment interaction, to make the decisions, arrange the work, say particular things, and disrupt the space and the dynamics in which students and teachers move.

As a field, we wanted to understand how teachers' mathematical knowledge matters for teaching and learning. We wanted to know this with more practical relevance and more theoretical clarity. We assumed that something about mathematical knowledge would affect the quality of teaching and learning. But what we need to be talking more clearly about is mathematical knowing and doing inside the mathematical work of teaching. This change from nouns- "knowledge" and "teachers" - to verbs - "knowing and doing" and "teaching"-is not mere rhetorical flourish. These words can support a focus on the dynamics of a revised fundamental question: what is the mathematical work of teaching? This question helps to ensure that we are not compartmentalizing and that we are talking about the dynamics of the work a teacher does as she teaches her students mathematics (see Lampert, 2001, for an extensive development of what is involved in unpacking the work involved in managing "problems of teaching").

What $i$ the "work of mathematics teaching" seen through a lens of practice? How do we calibrate the wide variety of work underway-about teaching, about theories of classrooms, about what mathematics is, about the larger environments of the work of teaching - to see, name, and understand the actual mathematical work of teaching? 


\section{Recalibrating the Question by Reconsidering "Teaching"}

The instructional triangle in Fig. 1 (Cohen, Raudenbush, \& Ball, 2003) makes visible that teaching is co-constructed in classrooms through a dynamic interplay of relationships, situated in broad socio-political, historical, economic, cultural, community, and family environments. These are constructed through the interpretations and interactions of teachers, students, and content. ${ }^{3}$

Students influence one another in myriad ways; what they already know about the content from prior experiences inside and outside of school influences them; how they read and understand their teachers also influences them. How their teachers interpret, respond, and treat them, as well as what their teachers know, believe, and understand about the curriculum, are all powerfully important. All of these relationships are interacting and influencing the learning in complex environments.

All of this complexity could make learning highly improbable. But the work of teaching is at its core about taking responsibility for attending with care to these chaotic and dynamic interactions. The work involves using skill, love, and knowledge to maximize deliberately the probability that students will learn worthwhile things and will flourish as human beings from being in that learning environment.

This is a probabilistic argument. Teaching does not cause learning-learners do the work of learning. However, the work of learning cannot be left to chance. Teaching is about doing caring and careful work in real time, with students, in specific contexts, that makes it the most likely that every student learns worthwhile skills, knowledge, dispositions, and qualities for their lives.

I refer to teaching practice as "work" to focus on what teachers actually $d o$ and to distinguish this focus from important foci on other features of classrooms, such as instructional formats, classroom culture and norms, what students are doing, and how the curriculum is designed. For example, small group work might be a feature in a classroom, but a focus on the work of teaching would probe what the teacher does to make small group work function well. The word "work" is intended to focus attention on what is involved in the doing of this responsibility of "maximizing the probability" that students will thrive and learn. Other aspects and features of classroom discourse, content, and interactions are also important but are not focused on what it takes to do the teaching.

What about problem solving or discussions or seatwork? Aren't those things that teachers do? Certainly teachers create seatwork. They use small groups. They facilitate discussions. But this does not help us understand from the inside of the work what it is to make small groups, or lead discussions, or create seatwork. What is it to ask a question in the moment - not thinking for a long time about what question might be asked, but actually producing the question in real time, fluently,

\footnotetext{
${ }^{3}$ See Ball and Forzani (2007) for a discussion of how this instructional triangle relates to and differs from other uses of "triangles" to represent teaching and learning.
} 
Fig. 1 Instructional triangle

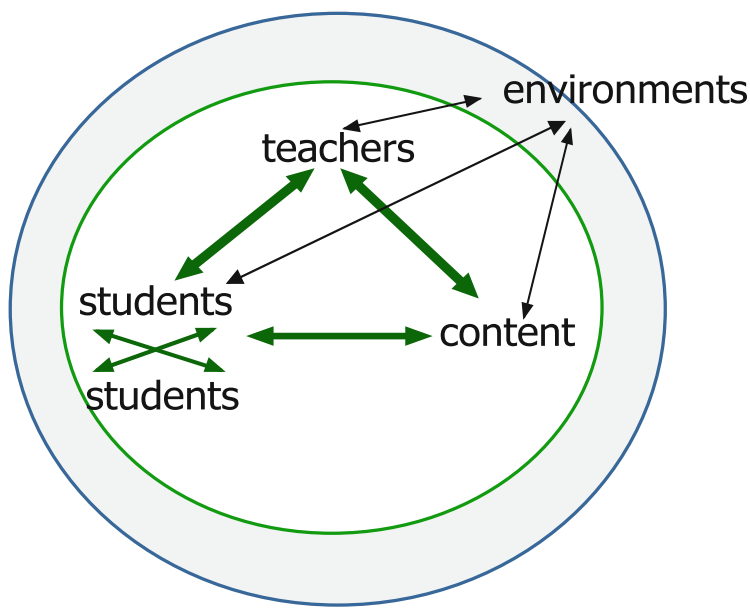

in a way that a child can understand it? What is involved in watching the children, listening to their talk, remembering what particular children said or did the day before, keeping in mind the point of the lesson (Sleep, 2012), and asking the next question, choosing the specific example, and deciding when and how to conclude the lesson for that day?

The use of "work of teaching" also represents a commitment to honor the effortful and deliberate nature of teaching. Learning does not happen by chance in classrooms. In fact, when the work of teaching is not as skillful as it might be, children do not learn. They are put at risk and they do not thrive. It is not respectful of the skill and effort entailed in teaching to represent it as intuitive, individual, or to render its details invisible. I use the word "work" to help us focus our lens not away from teaching, but more directly onto it.

There are many tools to draw upon to help us focus on the work of teaching. Drawing on the socio-cultural work of Anna Sfard, Jill Adler, and others, we know that classrooms are discursively intensive places that require a great deal of communication, both verbal and nonverbal, between and among students and teachers (Sfard, 2007; Adler \& Davis, 2006; Adler \& Ronda, 2015). We know that classrooms are filled with diversity that creates all kinds of resources and challenges for that discursive work. This means that there is something to the mathematically interactive, discursive, and performative work of mathematics teaching that is important to understand. In the next section, I turn to focus specifically on this "mathematical work of teaching." The goal is to see, name, and unpack the mathematical listening, speaking, interacting, fluency, and doing that are part of the work of teaching, not just resources for it. Focusing in this way on the mathematical doing that teaching entails can help shed light on the quest to understand the mathematics needed by teachers. 


\section{Seeing and Naming the Mathematical Work of Teaching}

How might we identify and illustrate what might be meant by the work of teaching, and in particular the mathematical work of teaching? Central to bear in mind is an inherent fact of teaching, namely, that teachers are always communicating, relating, and making sense across differences, including differences in age, gender identities, race and ethnicity, culture and religion, language, and experience. This important dimension of difference in identity and positionality means that a fundamental part of the work of teaching is being aware of and oriented to learning about and coordinating with others' perspectives. Teaching is not just about what the teacher thinks; it is about anticipating what others think and care about, and attuning one's talk, gestures, and facial expressions to how others might hear or read the teacher. It is about talking with one's ear toward what someone else thinks, knows, or understands. This is a special and difficult kind of talking. Little is understood about what it takes to do it interactively, on one's feet. Often when we think about explaining mathematics, for example, we search for a good explanation that we ourselves find compelling and that we can understand and can articulate. But the real talk of teaching focuses instead on explaining mathematics in a way that anticipates how the person to whom the teacher is talking might actually understand the teacher's words, or how that individual might hear the teacher. It is a strange kind of talking and unlike most of the talking we do in everyday life.

This feature of teaching "across difference" is made still more consequential because these differences are not merely individual and personal. It is not a neutral feature of the work of teaching. Rather, the significance of difference is embedded in the historical and persistent structures and normative patterns of practice that have excluded and marginalized minoritized groups. Consider, for example, the social identities and contexts of the children in the class we examine below. They attend public school in a low-income predominantly African American community in the United States. Few members of their families have attended college. The children are in grade 5 and range in age from 9 to 11 years; of the 30 students in the class, 22 are African American, four are Latinx, ${ }^{4}$ and four are White. Consider, too, the teacher's identity and position. Like the overwhelming majority of U.S. teachers, she is a White woman who attended predominantly White middle-class schools. Perhaps less like many U.S. teachers, growing up, she has been fluent in two other languages and experienced attending school as an emergent bilingual learner. Her public-school teaching experience over the last 40 years has been entirely with children of color and bilingual children, primarily of middle and working class families. The differences and connections between her identity and positionality and those of the children and their families are crucial to the forging of their relationships and communication. These differences matter for the imperative to connect with them and earn their trust. This is all fundamental to the work, and the mathematical work, of teaching.

\footnotetext{
4"Latinx" is used to avoid conveying a binary representation of gender identity.
} 


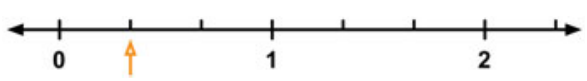

What number does the orange arrow point to? Explain how you know.

Fig. 2 Naming one-third on the number line (beginning of lesson)

Many of the children in this particular class - and in many in U.S. classroomshave not had successful experiences with mathematics in school. They have come to think of being "smart" as getting right answers and good grades. Because of what they have come to see as "mathematics" and what it means to do well at it, by age 10 many of the children have begun to think they are not particularly good at math. These children, most of whom are African American or Latinx, refer to having gotten low marks on tests or to not getting right answers. Many have been "in trouble" in school for not "paying attention" or "talking" to others when they are supposed to be working quietly. Thus, their identities are already shaped by these structures of institutionalized racism and normalized practices of instruction (Nasir, Shah, Snyder, \& Ross, 2012). The work for the teacher is situated in these broader systemic and historical patterns and is, in the moment, about connecting with and supporting these particular children and their opportunities to learn and grow (Nasir, 2016). In teaching, considerations of the individual and the systemic, the present and the historical, come together in the minute-to-minute of classroom dynamics. And they are embedded in and inextricably intertwined in subtle issues of mathematical ideas and talk, relationships, and maintaining a classroom environment focused on learning. Whereas research can be analytic, and can take apart the complex phenomena in order to probe and understand them, teaching is an integral and interactive whole. Studying the work of teaching therefore necessarily requires that we seek ways to see and understand that integration and simultaneity of differences.

To unpack what this might mean, we turn next to look inside the classroom where these children are learning mathematics. As we notice their work and their thinking, our purpose is to try to consider the surrounding integral work of teaching that is supporting their mathematics learning.

\section{The Work of Teaching in One Lesson}

On this particular morning, the children have worked on the problem in Fig. 2 in their notebooks.

This problem represents a significant turning point in the class's mathematical work, from naming fractions as parts of areas to identifying fractions as points on the number line. One important shift is to understand that on the number line, the whole is defined as the interval from 0 to 1 . With area models, the whole can be 
Fig. 3 Naming fractions as parts of wholes

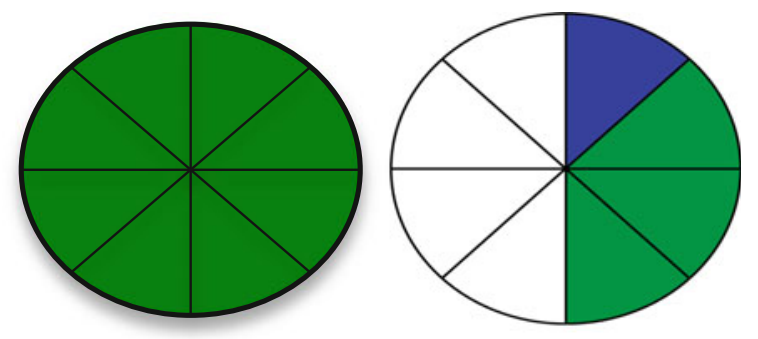

greater than 1. For example, in Fig. 3, it is possible to name the green shaded portion as $13 / 8$ or $11 / 8$, if one identifies one circle as the whole. But it is also correct to identify two circles as the whole, and then the fractional part that is green is $11 / 16$.

For the children, it is an important new understanding to learn that, on the number line, the whole is always defined as the interval from 0 to 1 and the problem on which they are working is designed to press on this issue and bring it to explicit understanding.

During the beginning of class, known as the "warm up" (about five minutes), the children pasted this opening problem in their individual notebooks and wrote their answers and explanations individually. The correct answer is 1/3. Eight (6 African American, 1 Latinx, and 1 White) children do have $1 / 3$ as the answer, but no one has explained his or her answer. The other 22 children have other answers, including $1 / 4,2 / 4$, and 1 .

See Fig. 4 for some examples of what students have in their notebooks before the class discussion.

The teacher has been walking around while the children are thinking and writing and has been looking at the range of ideas and explanations, noticing what different children have written and thinking about what will be important to work on together.

The teacher launches the class discussion of the problem. ${ }^{5}$ The children are seated at tables arranged in a U-shape, and they are all able to see the large white boards at the front of the room, on which the problem is drawn.

Teacher: (standing near the back of the room) Who would like to try to explain what you think the answer is? And show us your reasoning by coming up to the board? Who'd like to come up to the board and try to tell- And you know, it might not be right. That's okay because we're learning something new.

I'd like someone to come up and sort of be the teacher and explain how you are thinking about it. Who'd like to try that this morning? (Several children raise their hands to volunteer.)

\footnotetext{
${ }^{5}$ The video for this segment is available for viewing at http://hdl.handle.net/2027.42/134321.
} 


\begin{tabular}{|c|c|}
\hline Ashton & What number does the orange arrow point to? \\
\hline Dante & $\begin{array}{l}\text { What number does the orange arrow point to? } \frac{\frac{1}{2}}{\text { Explain how you know Because if you }} \\
\text { loolh of it and Caunt. }\end{array}$ \\
\hline Lakeya & 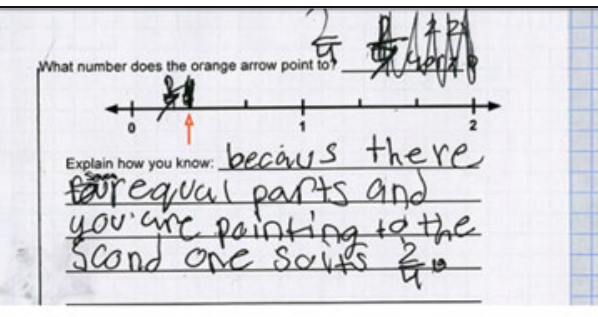 \\
\hline Makayla & 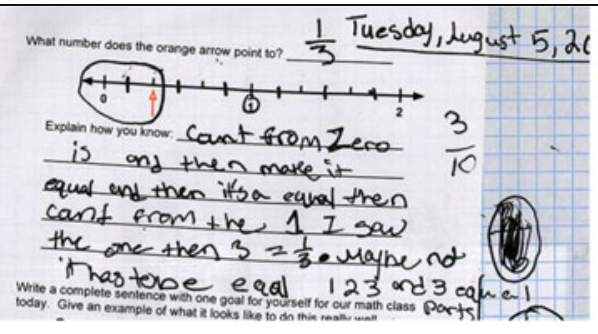 \\
\hline Mariana & 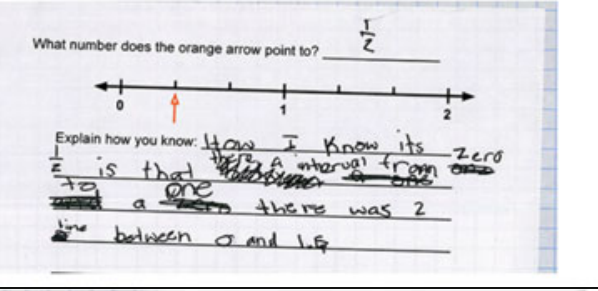 \\
\hline Parker & $\begin{array}{l}\text { What number doess the orange arrow point to? } \frac{0}{5} \\
\text { Explain now you know Because if you } \\
\text { count by ones you get zero } \\
\text { overtive. }\end{array}$ \\
\hline
\end{tabular}

Fig. 4 Children's work on the number line problem at the beginning of class 
Okay, Aniyah? (Aniyah, a Black girl, gets up from her seat and walks to the whiteboard at the front of the classroom.) When someone's presenting at the board, what should you be doing?

Students: Looking at them.

Teacher: Looking at that person-uh-huh.

Aniyah: (to the teacher) You want me to write it?

Teacher: (to Aniyah) You're trying to mark what you think this number is and explain how you figured it out.

(to class) Listen closely and see what you think about her reasoning and her answer. (Teacher moves to back of the classroom; Aniyah is in front at the whiteboard. Aniyah writes $1 / 7$ by the orange line).

Aniyah: I put one-seventh because there's-

Toni, an African American girl, sitting close to where Aniyah is standing, asks quietly, almost to herself: "Did she say one-seventh?" Hearing her question, Aniyah turns toward her and nods: "Yeah. Because there's seven equal parts, like one, two, three, four, five, six, and then seven," and demonstrates using her fingers spread to measure the intervals to count the parts on the number line.

Teacher: (still standing at the back, addresses the class) Before you agree or disagree, I want you to ask questions if there's something you don't understand about what she did. No agreeing and disagreeing. Just —all you can do right now is ask Aniyah questions. Who has a question for her?

Okay, Toni, what's your question for her?

Toni: $\quad$ Why did-(looks across at children opposite her and laughs, twisting her braid on top of her head)

Teacher: (to Toni) Go ahead, it's your turn.

Toni: (to Aniyah) Why did you pick one-seventh? (Toni giggles, twisting her braid.)

Dante: (laughing across the room at Toni) You did not!

Teacher: Let's listen to her answer now. (to Toni) That was a very good question. (to Aniyah) Can you show us again how you figured that- why you decided one-seventh?

Aniyah: First, I thought it might be seven because there's seven equal parts.

Teacher: Did you write one-seventh? I can't see very well from here.

Aniyah: Uh-huh. Yes.

The teacher nods affirmatively, and turns to the class, "Okay, any more questions for Aniyah? In a moment, we're going to talk about what you think about her answer, but first, are there any more questions where you're not sure what she said, or you'd like to hear it again or something like that? Lakeya?"

Lakeya: (looks back at the teacher at the back of the room) If you start at theTeacher: (gestures toward Aniyah) Talk to her, please. 
Lakeya: Oh! (turns toward Aniyah) If you start at the zero, how did you get oneseventh?

Aniyah: Well, I wasn't sure it was one-seventh, but first, I thought that the seven equal parts.

Teacher: Okay, would some- You'd like to ask another question, Dante?

Dante: Yeah.

Teacher: Yes, what?

Dante: So, if it's at the zero, how did you know that if like if I took it and put it at the- Hold on. Which line is- What if it didn't like- What if the orange line wasn't there, and you had to put it where the one is? What if the orange line wasn't there? And how would you still know it was one-seventh to put it where the orange line is now?

Aniyah: (pauses) I don't know.

Teacher: (pauses) Okay. Does everyone understand how Aniyah was thinking?

Students: Yes.

Teacher: Yes? Okay. (to Aniyah) You can sit down now. We're going to try to get people to comment. Do you want to take comments up there? Would you like to stand there and take the comments, or do you want to sit down and listen to the discussion?

What would you prefer?

Aniyah: Sit down.

Teacher: Sit- You'd like to sit down? Okay.

During these three minutes of class, four children speak in the whole group discussion: Aniyah, Toni, Lakeya, and Dante. The class discussion continues for another 48 minutes. During this time, the discussion emphasizes the importance of partitioning the unit interval in equal parts and being sure to count spaces (i.e., intervals, not hash marks) to determine the distance from 0 for a given point on the line. The students practice naming points on the line and also explaining carefully with reference to the "whole" and to "equal parts" and to counting spaces to determine the number.

At the end of the lesson, to learn what the children are thinking now, the teacher chooses a new fraction and a new number line and poses the question in Fig. 5 for the children to answer independently in their notebooks.

The correct answer is $2 / 3$, and the target explanation would draw on the notions of the whole (the interval from 0 to 1 ), equal partitions of that whole, naming one part, and naming the number of equal parts (Fig. 5).

The results are interesting. Before the class discussion, when working independently on the problem in Fig. 2, 8 children (27\%) can correctly name the point on the number line with a correct number name, but without a clear mathematical justification. 22 have other answers. After the discussion, $26(87 \%)$ can label the point correctly and can provide mathematical explanations for their choice. Of the four students who did not name the point correctly, they nevertheless refer to important aspects of the definition, including "equal parts" and "spaces." 
1. What number does the blue arrow point to?



Explain how you figured this out:

Fig. 5 Naming two-thirds on the number line (end of class)

Fig. 6 shows the work on the end-of-class check by the same six students whose beginning-of-class problems are shown in Fig. 4. It is interesting to compare their answers before and after the 51-minute in-class discussion of how to name fractions as points on the line.

\section{What Is the (Mathematical) Work of Teaching?}

We examined only three minutes of a lesson. This is in some ways little time, yet it is filled with intense demands on the teacher. What does studying this segment closely reveal about the work of teaching? What, for example, is involved in setting up and guiding the children to think about and learn mathematics? To listen to one another? To have confidence in their own thinking? What is involved for the teacher in tracking on what each of the 30 children is thinking, puzzling about, and learning? In knowing who might be drifting off and who might be feeling confused?

One key element of the work has occurred earlier: the decision about the problem to pose. Before the discussion described above, the students had individually worked on and answered the question in their notebooks. Even before that, the teacher had decided on the task. Why the number $1 / 3$ ? Why, for example, a unit fraction? Why also draw a number line that extends just a little past 2? Would it have worked the same way with a number line precisely drawn from 0 to 1 ? What if the point she had selected was $1 / 4$ or $4 / 5$ instead of 1/3? Each of these decisions shaped the mathematical context in which the children were immersed, and created the space for their thinking, writing, and learning.

A second aspect of the work of teaching is to see and make sense of the work of individual children while they are working on the task. To do this, the teacher circulated around the room to scan what the children were writing in their notebooks. She did this to get a sense of what the children were thinking and to see the range of answers in the room. Reading children's writing and reasoning is mathematically demanding. Notice how this sort of examination is different than being a researcher on students' thinking and using digitized copies of students' work with a 


\begin{tabular}{|c|c|}
\hline Ashton & $\begin{array}{l}\text { 1. What number does the blue arrow point to? } \\
\text { Explain how you figured this out It is ane } \\
\text { half because. It is two spaces } \\
\text { between } 0 \text { and the arrow. }\end{array}$ \\
\hline Dante & $\begin{array}{l}\text { 1. What number does the blue arrow point to? } \\
\text { Explain how you figured this out you have to } \\
\text { Count the space. }\end{array}$ \\
\hline Lakeya & $\begin{array}{l}\text { 1. What number does the blue arrow point to? } \\
\text { Explain how you figured this out Becavs } \\
\text { sal Whent the he wil was. } \\
\text { then I mane shure it had equalpaiss }\end{array}$ \\
\hline Makayla & $\begin{array}{l}\text { ENO Of CLASS CHECK m: Tuesdar. August 5, } 2014 \\
\text { 1. What nymber doeg the blve anow point lo? }\end{array}$ \\
\hline Mariana & $\begin{array}{l}\text { END OF CLASS CHECK } 27 \text { : Tuesday, August 5, } 2014 \\
\text { 1. What number does the blue arrow point to? } \\
\text { Explain how you figured this out I counted the } \\
\text { space there where } 3 \text { space } \\
\text { in trotal there where } 2 \text { space } \\
\text { where the arrow so I got } \frac{2}{3}\end{array}$ \\
\hline Parker & $\begin{array}{l}\text { 1. What number does the blue arrow point to? } \\
\text { Explain how you figured this out Becausc you } \\
\text { half to count by the equal } \\
\text { mesherments as. Whe axher ones. }\end{array}$ \\
\hline
\end{tabular}

Fig. 6 Children's work on the number line problem at the end of class 


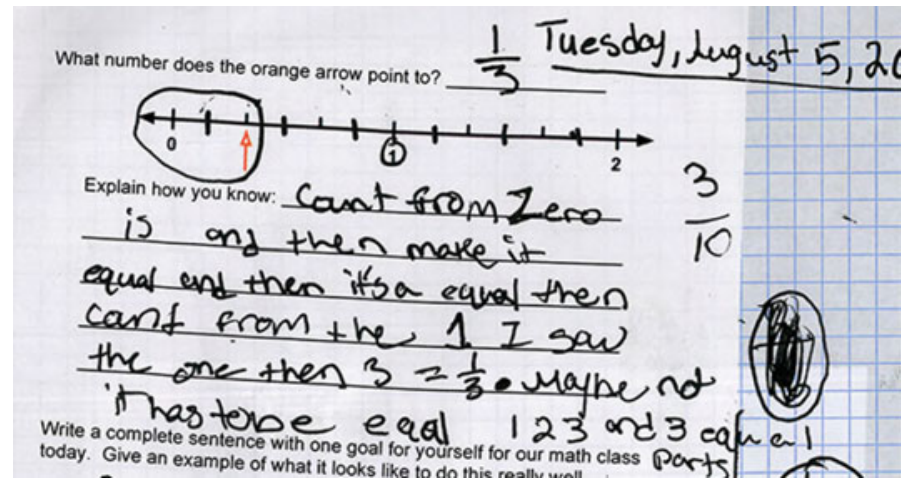

Fig. 7 Makayla's notebook before the class discussion

lot of time to examine and mark things and notice nuances. Instead, the work of teaching requires thinking and reading mathematically in real time. It involves walking around the room, surveying and trying to read 30 different responses, including the numbers they have identified and the explanations written. It involves sorting them mentally, and making a careful decision about choosing which answer to begin the discussion and whom to call on.

For example, what is Makayla thinking? (Fig. 7).

She records $1 / 3$ but also writes $3 / 10$, and explains in detail, "Count from zero is and then make it equal and then it's a equal then count from the 1 I saw the one then $3=1 / 3$. Maybe not. It has to be equal. 123 and 3 equal parts." Her use of the equals sign is of interest, signaling that after counting three equal parts, the number she writes is $1 / 3$. Her circling of the segment of the number line up to the orange arrow also shows her focus on the three, starting at 0 . What does she think the whole is? Reading children's mathematical writing and representations is not linear, reading from top to bottom in order. Instead, reading as a teacher requires a more multi-directional examination, making sense of the logic, detecting where the writing is sequential and where it is discontinuous, either in time or thinking. For example, does Makayla think that $1 / 3$ is the same number as 3/10 or did she change her mind and not cross it out? Some of what is involved is general and some involves knowing the particular child and some of her ways of expressing. Makayla tends to make a diagram or representation before writing, and sometimes goes back and forth as she represents her explanation, altering the diagram and writing a new thought based on that. She, like many other children, does not always cross out something about which she has changed her mind.

And what does Dante's explanation suggest about his thinking? (Fig. 8).

One part of reading is the actual decoding of children's writing accurately. Here Dante writes, "Because if you look at it and count." The words "look" and "count" might not be easy for readers not skilled in reading and interpreting children's writing. What is he saying exactly? Does Dante think it is $1 / 2$ because it is between 


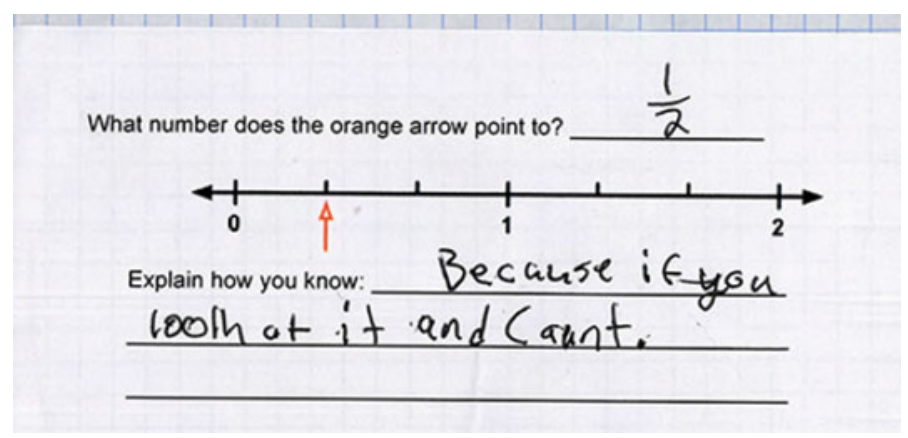

Fig. 8 Dante's notebook before the class discussion

0 and 1 , a common idea, or is it because he started at 0 and counted the tick marks at 0 and at 1 ?

The work of teaching involves a fluency of mathematical reading and interpretation, to surmise what 30 (or more) different children might mean, and preparing to ask questions or to probe wisely or to comment strategically, all in real and rapidly moving time. At least three kinds of reasoning and interpretation are involved. First is to consider the mathematical issues embedded in the task or problem. For example, this task involves interpreting the number line, including what is considered the "whole," what to count - intervals or tick marks - and how to determine the name of a point on the number line. That the point is named by the distance from 0 in terms of the number of intervals of a particular length (e.g., 1/3) embeds all of these dimensions. Reading children's writing is supported if the reader has a firm orientation to the things that a child's representation contains. Second, and closely related, is to anticipate how the children might interpret the task or decide on their answer. Knowing, for example, that many children might count tick marks instead of intervals or start at 0 instead of at 1 can help a reader to see and interpret what a child has written. Finally, this work entails a fluency in reading children's written representations, including spelling, spacing, handwriting (formation and orientation of letters, numbers, and symbols), ellipses and missing words or letters, and the composition on the page (for instance, that their writing is often not linear from top to bottom).

There is also the complex work of leading a discussion, often misleadingly represented as "getting out of the way" and "letting the children do the teaching." First, the teacher chooses whose work launches the discussion. This is a key and consequential decision. In this case, while circulating as the children worked independently, the teacher saw many different answers by different children. Her decision about whose answer to start with involves considering the particular children and how they are positioned in the class and how who gets the floor and is given recognition for their thinking influences that positioning. The teacher's decision also involves thinking about the mathematical issues on which the children are focused and those key to her instructional goal. She chooses Aniyah to present 
1/7, which puts the issue of the "whole" in focus, and provides an opportunity to position this African American girl as competent because of the clarity of her mathematical explanation, structured logically and based on the core elements of the definition (Boaler \& Staples, 2008; Cohen \& Lotan, 2003; Featherstone et al., 2011).

To be sure, when Aniyah presents her answer (1/7), the teacher is physically out of the way. She stands at the back of the room, and she does position Aniyah in the role of "teacher." But to see this as moving away and letting the children have the freedom to learn misleads us about the intricacy of the work. The teacher firmly structures the discourse: "No agreeing and disagreeing. Just-all you can do right now is ask Aniyah questions." This move shapes what the children may talk about. Instead of jumping to offer another answer, they must think about what Aniyah wrote and explained, compare it with what they wrote in their own notebooks, and ask some sort of question. This move buffers a possible tendency to develop patterns of discourse that are all about critique, objection, and competition to be "right," rather than about careful attention, consideration, and collective development of ideas and arguments.

Setting the children up to do the work of learning also involves careful work for the teacher. She must watch Aniyah closely and be ready to offer support for her presentation if it seems needed. She watches the other children: Are they following? When Toni giggles while posing a question to Aniyah, the teacher can choose to interpret her as making fun of her classmate-or she can read her as seriously engaged in her classmate's idea. Toni, who has an unexplained 1/3 in her notebook, asks, "Why did you pick one-SEVENTH?" The teacher must take note of her emphasis on the "seventh" - this, after all, diverges from her choice of "third." And less than a minute later, Lakeya, who has written 2/4 in her notebook, asks, "If you start at the zero, how did you get one-seventh?" and now the teacher must hear the emphasis on the "one" for Lakeya has TWO fourths. Listening like this entails a close and mathematically sensitive attention, which draws not on the teacher's own knowledge of $1 / 3$ as the answer, but on her ability to focus on the children's thinking and talk. This focus on hearing others' mathematical thinking, through their talk, gesture, inflection, and tone, depends on deliberately suspending quick assumptions about what others mean, but yet listening in mathematically nimble ways. To name the work of discussion-leading as moving out of the way and "facilitating" is reductive and misrepresents the multiple aspects of the careful work of teaching.

The work of teaching involves disrupting the tendency to classify children's answers as either correct or incorrect. Helping children learn depends on seeing what they do know and can do, not absorption with what is missing. This is neither natural nor obvious. Math is a subject, perhaps like spelling, in which the focus is often on errors. For Aniyah, the main thing most observers notice is that her answer is wrong. For Toni, people notice she is playing with her hair, they interpret her as trying to get attention from other children in the class, and they often think she is trying to embarrass Aniyah. These reactions are shaped not only by the tendency to notice mistakes but also by the reproduction of racialized and gendered biases that mask these African American girls' strong mathematical capabilities (Martin, 


\begin{tabular}{|l|l|}
\hline Aniyah & Toni \\
\hline - Uses the correct definition for a fraction: & - Listens closely to a classmate's \\
- She identifies the "whole"; & presentation. \\
$\begin{array}{l}\text { - She makes sure the intervals are equal; } \\
\text { - She counts intervals and not tick marks; }\end{array}$ & - Uses the definition for a fraction to ask \\
and & - Asks a pointed mathematical question. \\
$\begin{array}{l}\text { - She knows how to write "one-seventh". } \\
\text { - Produces a mathematically well-structured } \\
\text { explanation. }\end{array}$ & \\
- Presents her ideas clearly. & \\
\hline
\end{tabular}

Fig. 9 Aniyah's and Toni's mathematical competence

2015). The persistent patterns of marginalization of particular groups are certainly produced and reproduced in systemic ways. In fact, both Aniyah and Toni know and can do a lot. The work of teaching involves actively seeing and naming what each girl shows she knows and can do (Fig. 9).

The work of teaching involves not only seeing and naming the girls' mathematical competence with fractions, definitions, and explanations, but also attending to their positioning and their mathematical identities, and building on their strengths and resources to support their growth (Langer-Osuna, 2016).

Many other examples of the mathematical work of teaching can be seen in this lesson. The teacher kneels beside a student to talk to her about how she understands a problem and to respond to her in a way that is mathematically sensible, that she can understand, and that does not distort the math. When Aniyah is at the board, teaching involves listening carefully to what she is saying and showing and what others are asking or commenting, and watching carefully to see how Aniyah is experiencing this attention on her answer. Based on these, there is the deciding whom to call on next, whether to make a point oneself, or whether to revoice or ask a student to restate what has been said, or perhaps allow another student to comment. Another example is translating from intensively mathematical (e.g., "Understand a fraction $1 / b$ as the quantity formed by 1 part when a whole is partitioned into $b$ equal parts"- a learning goal in the U.S. Common Core Standards for Mathematics) to usable terms (e.g., using a variable notation such as "call one of the equal parts $1 / \mathrm{d}$ " to represent the unit fraction). And this also involves being able to "talk" the terms, saying them in accessible ways and helping the children learn to talk with them. Still another is deciding whom to name as competent and how to intervene on inequities that may be reproduced in the classroom (Boaler \& Staples, 2008; Cohen \& Lotan, 2003; Featherstone et al., 2011).

Each of these represents part of the intricate mathematical work of teaching. It is not an exhaustive list, but the examples illustrate the mathematical aspects inside particular moves or interpretations. Naming them as "mathematical" is not intended to suggest that mathematical reasoning is all that is involved. Rather, the point is that these decisions, moves, ways of talking, doing, and moving, all crucially 
involve mathematical sensibility, thinking, and understanding. For example, it would not be possible to identify competence in students' work in a high school chemistry or music class without being fluent in these domains in the special ways demanded for teaching. Without substantial and nuanced understanding of the domain and its practices, one would not be able to read and interpret student writing, pose questions, or revoice students' comments. Neither could one broaden students' notions about what competence is in that domain and see and name students' competence in ways that would intervene on status hierarchies.

\section{Conclusion}

The quest to answer the perennial question of what mathematical "knowledge" teachers need should be based on a deep and nuanced understanding of what teachers actually do. How does mathematical listening and hearing, as well as writing, representing, and talking play a role in the work of teaching? What sorts of mathematical sensibility and insight matter for seeing minoritized children as not deficient but as emergent and thoughtful mathematical thinkers and actors? What mathematical disposition and fascination does it take to nurture children's seriousness as thinkers and their creative playfulness as mathematical explorers? When Toni asks, "Did she one-seventh?" as she watches her classmate present, she is seriously surprised. When Dante asks, "What if the orange line wasn't there, and you had to put it where the one is?" he is genuinely wondering. Respecting and nourishing the brilliance of these African American children entails a kind of mathematical care that deserves acknowledgement (Leonard \& Martin, 2013). Probing and naming the work of teaching means identifying and articulating what is involved in these many, complex, and simultaneous actions, decisions, and moves entailed in the broader and moment-to-moment intellectual and moral tasks and considerations of the work. It means coming to see not just what an observer or an analyst might see or infer, but what is involved in actually doing those things, from the inside.

Trying to study the work of teaching from the perspective of what is involved in doing it presents several challenges. One challenge is that teaching is fundamentally relational work. This means that the work is constructed simultaneously with individual children, who are themselves not static and whose identities-in-action are refracted through their memberships in multiple and overlapping communities. The work of teaching is also constructed in the social contexts of the collective setting, as well as in the broader socio-political, historical, and community contexts (Lampert, 2001). Uncovering the work from this perspective is crucial, yet it is easier to focus on one dimension, such as the teacher's questioning of one student or her representation on the board. However, to understand the work of teaching, the simultaneity and complexity are fundamental (Ball \& Lampert, 1999). This implies that interdisciplinary teams and tools and methods to get inside the work will be important (see Bullock, 2012, for a useful discussion of methodological 
choices). It will often be confusing to distinguish the effort to study the work of teaching from other worthwhile foci for classroom studies or studies of teachers, which contribute importantly to our understanding of classrooms and of teaching, learning, students, and teachers.

A second challenge regards the issue of teaching quality, and normative versus descriptive perspectives on the work of teaching. Does the teaching used to study the work have to be skillful? And what should that mean and who or what would determine this? How would considerations of equity and the disruption of dominant norms and reproduction figure in such appraisals, or of mathematical integrity, or of caring? One might examine teaching work from the perspective of the endemic problems to be managed (Kennedy, 2016; Lampert, 2001), but this would not resolve the issue of whether some approaches to managing would more useful—or not worthwhile - to study. Who would decide what teaching is worth studying and how would such decisions either focus or constrain the effort to understand the work of teaching? Bullock (2012) argues that decisions about what and how to study should be guided by the moral imperative to "make life better for people," to serve the interests of children, families, and communities who have been marginalized and disenfranchised. How can our study of the work of teaching be careful not to be falsely "impartial" but, instead, to honor the goal of making responsive and responsible teaching learnable by others? This implies making and justifying explicitly deliberate decisions about the practice to be studied.

A third is that existing theoretical frames and the aspects of teaching that are already used or studied will make it difficult to focus on some aspects of the work of teaching, such as reading students" work "on the fly" and processing it to prepare for launching a discussion, or disrupting normative practices of control. In the case of reading students' work, and considering whose work might be good to invite to share in a discussion and why, there are many things that the teacher is doing, some visible and some invisible (Lewis, 2007). Some of the most important demands of studying the work of teaching will be to see and name aspects of the doing that are taken for granted and so lack names or foci. Another will be the acts that are "not-doings." Some of the work of teaching is to refrain purposefully at a given moment from doing something, such as rebuking a child for fidgeting or talking in class (Noel, 2014), interrupting a child's language, or explaining a "standard" method. These other invisible (Lewis, 2007) but deliberate acts are surely also to be included in our unpacking of the work of teaching.

The third challenge leads to a fourth — namely, what should be the warrants for claiming that a particular move or non-move, a particular action or thought, is part of the work of teaching? Because, as in many domains of expertise, skillful performance is often partly tacit, teachers might not always be able to articulate the inside work, or to name the complex intertwined kinds of moves, ways of talking, and practices on which their practice is built. What does it mean, then, for an observer to claim that something is part of that work when the person doing it cannot isolate or name it? Examining the work of teaching requires careful consideration of this challenge and ways of using productively both insider and outsider perspectives. 
Finally, threaded throughout a focus on the work of teaching is the challenge of examining and identifying the mathematical entailments of that work. This is a complex undertaking that will require ongoing articulation of what counts as "mathematical," and what it means for work to "demand" mathematical reasoning, knowing, thinking, or talking (Ball, 1999). Hoover (2009) argues that this work involves coordination of perspectives, not merely annotating practice with mathematical commentary or analysis. What is the mathematical reading involved in scanning children's writing and representations? What kinds of mathematical interpretation and reasoning does this take? What does it take to teach mathematics in ways that disrupt dominant patterns of marginalization?

Answering questions such as these will not be easy, but the potential is important. For it is through such analysis and naming that we will come to understand much more about the ways in which the teaching of mathematics requires specialized mathematical ways of thinking and reasoning. And it is with such insight that we will make headway on the longstanding and important question of how teachers need to know mathematics in and for their work.

Acknowledgements The author is grateful to and acknowledges her colleagues who have helped her learn across time and have influenced her thinking about the ideas in this paper: Hyman Bass, Esther Enright, Susanna Farmer, Rebecca Gadd, Nicole Garcia, Imani Goffney, Lauren Hickman, Mark Hoover, Lindsey Mann, Blake Noel, Sabrina Salazar, Meghan Shaughnessy, Rachel Snider, Charles Wilkes, and Amber Willis.

The work discussed in this paper has been supported for more than 20 years by grants from the National Science Foundation to the author, and her colleagues, Hyman Bass, Heather Hill, Mark Hoover, and Laurie Sleep.

\section{References}

Adler, J., \& Davis, Z. (2006). Opening another black box: Researching mathematics for teaching in mathematics teacher education. Journal for Research in Mathematics Education, 37(4), 270-296.

Adler, J., \& Ronda, E. (2015). A framework for describing mathematics discourse in instruction and interpreting differences in teaching. African Journal of Research in Mathematics, Science and Technology Education, 19(3), 237-254.

Ball, D. L. (1990). The mathematical understandings that prospective teachers bring to teacher education. Elementary School Journal, 90(4), 449-466.

Ball, D. L. (1999). Crossing boundaries to examine the mathematics entailed in elementary teaching. In T. Lam (Ed.), Contemporary mathematics (pp. 15-36). Providence: American Mathematical Society.

Ball, D. L., \& Forzani, F. M. (2007). What makes education research "educational"? Educational Researcher, 36(9), 529-540.

Ball, D. L., \& Lampert, M. (1999). Multiples of evidence, time, and perspective: Revising the study of teaching and learning. In E. Lagemann \& L. S. Shulman (Eds.), Issues in education research: Problems and possibilities (pp. 371-398). San Francisco: Jossey Bass.

Ball, D. L., Lubienski, S., \& Mewborn, D. (2001). Research on teaching mathematics: The unsolved problem of teachers' mathematical knowledge. In V. Richardson (Ed.), Handbook of research on teaching ( $4^{\text {th }}$ ed.) (pp. 433-456). New York: Macmillan. 
Ball, D. L., Thames, M. H., \& Phelps, G. (2008). Content knowledge for teaching: What makes it special? Journal of Teacher Education, 59(5), 389-407.

Baumert, J., Kunter, M., Blum, W., Brunner, M., Voss, T., Jordan, A., et al. (2010). Teachers' mathematical knowledge, cognitive activation in the classroom, and student progress. American Educational Research Journal, 47(1), 133-180.

Blömeke, S., Hoth, J., Döhrmann, M., Busse, A., Kaiser, G., \& König, J. (2015). Teacher change during induction: Development of beginning primary teachers' knowledge, beliefs and performance. International Journal of Science and Mathematics Education, 13(2), 287-308.

Boaler, J., \& Staples, M. (2008). Creating mathematical futures through an equitable teaching approach: The case of Railside School. Teachers' College Record, 11(3), 608-645.

Borko, H., Eisenhart, M., Brown, C. A., Underhill, R. G., Jones, D., \& Agard, P. C. (1992). Learning to teach hard mathematics: Do novice teachers and their instructors give up too easily? Journal for Research in Mathematics Education, 23(3), 194-222.

Bruckmaier, G., Krauss, S., Blum, W., \& Leiss, D. (2016). Measuring mathematics teachers' professional competence by using video clips (COACTIV video). ZDM Mathematics Education, 48(1-2), 111-124.

Bullock, E. C. (2012). Conducting "good" equity research in mathematics education: A question of methodology. Journal of Mathematics Education at Teachers College, 3(2), 30-36.

Carrillo, J., Climent, N., Contreras, L. C., \& Muñoz-Catalán, M. C. (2013). Determining specialised knowledge for mathematics teaching. In B. Ubuz, C. Haser, \& M. A. Mariotti (Eds.), Proceedings of the eighth congress of the European Society for Research in Mathematics Education.

Cohen, D. K., Raudenbusch, S., \& Ball, D. L. (2003). Resources, instruction, and research. Educational Evaluation and Policy Analysis, 25(2), 119-142.

Cohen, E. G., \& Lotan, R. A. (2003). Equity in heterogeneous classrooms. In J. A. Banks \& C. A. M. Banks (Eds.), Handbook of multicultural education (2nd ed., pp. 736-752). San Francisco, CA: Jossey-Bass.

Conference Board of Mathematical Sciences. (2001). The mathematical education of teachers. Providence RI and Washington DC: American Mathematical Society and Mathematical Association of America.

Conference Board of Mathematical Sciences. (2012). The mathematical education of teachers II. Providence RI and Washington DC: American Mathematical Society and Mathematical Association of America.

Dewey, J. (1902). The child and the curriculum. Chicago, IL: The University of Chicago Press.

Featherstone, H., Crespo, S., Jilk, L. M., Oslund, J. A., Parks, A. N., \& Wood, M. B. (2011). Smarter together! collaboration and equity in the elementary math classroom. Reston, VA: National Council of Teachers of Mathematics.

Goffney, I. M. (2010). Identifying, defining, and measuring equitable mathematics instruction. (Unpublished doctoral dissertation). University of Michigan, Ann Arbor, MI.

Goffney, I. M. (2014). Mathematical quality and equity video codes: Identifying and measuring equitable mathematics instruction. Manuscript in preparation.

Goffney, I. M., \& Hoover, M. (2017). Developing a theory of mathematical knowledge for equitable teaching. Manuscript in preparation.

Herbst, P., \& Chazan, D. (2015). Using multimedia scenarios delivered online to study professional knowledge use in practice. International Journal of Research and Method in Education, 38(3), 272-287.

Herbst, P., \& Kosko, K. (2014). Mathematical knowledge for teaching and its specificity to high school geometry instruction. In J. Lo, K. R. Leatham, \& L. R. Van Zoest (Eds.), Research trends in mathematics teacher education (pp. 23-45). New York, NY: Springer.

Hiebert, J., Morris, A. K., \& Glass, B. (2003). Learning to learn to teach: An "experiment" model for teaching and teacher preparation in mathematics. Journal of Mathematics Teacher Education, 6(3), 201-222. 
Hill, H. C. (2007). Mathematical knowledge of middle school teachers: Implications for the No child left behind policy initiative. Educational Evaluation and Policy Analysis, 29, 95-114.

Hill, H. C. (2011). The nature and effects of middle school mathematics teacher learning experiences. Teachers College Record, 113(1), 205-234.

Hill, H. C., \& Ball, D. L. (2004). Learning mathematics for teaching: Results from California's Mathematics Professional Development Institutes. Journal for Research in Mathematics Education, 35, 330-351.

Hill, H., Ball, D. L., \& Schilling, S. G. (2008). Unpacking "pedagogical content knowledge": Conceptualizing and measuring teachers' topic-specific knowledge of students. Journal for Research in Mathematics Education, 39(4), 372-400.

Hill, H. C., Schilling, S. G., \& Ball, D. L. (2004). Developing measures of teachers' mathematics knowledge for teaching. The Elementary School Journal, 105(1), 11-30.

Hill, H. C., Rowan, B., \& Ball, D. L. (2005). Effects of teachers' mathematical knowledge for teaching on student achievement. American Educational Research Journal, 42(2), 371-406.

Hoover, M. (2009). Coordinating mathematical and pedagogical perspectives in practice-based and discipline-grounded approaches to studying mathematical knowledge for teaching. Unpublished doctoral dissertation, University of Michigan, Ann Arbor, MI.

Hoover, M., Mosvold, R., \& Fauskanger, J. (2014). Common tasks of teaching as a resource for measuring professional content knowledge internationally. Nordic Studies in Mathematics Education, 19(3-4), 7-20.

Kaiser, G., Busse, A., Hoth, J., König, J., \& Blömeke, S. (2015). About the complexities of video-based assessments: Theoretical and methodological approaches to overcoming shortcomings of research on teachers' competence. International Journal of Science and Mathematics Education, 13(2), 369-387.

Kennedy, M. (2016). Parsing teaching practice. Journal of Teacher Education, 67, 6-17.

Knievel, I., Lindmeier, A. M., \& Heinze, A. (2015). Beyond knowledge: Measuring primary teachers' subject-specific competences in and for teaching mathematics with items based on video vignettes. International Journal of Science and Mathematics Education, 13(2), 309-329.

Lampert, M. (2001). Teaching problems and problems of teaching. New Haven, CT: Yale University Press.

Langer-Osuna, J. (2016). The social construction of authority among peers and its implications for collaborative mathematics problem solving. Mathematical Thinking and Learning, 18(2), 107124.

Lewis, J. (2007). Teaching as invisible work. Unpublished doctoral dissertation, University of Michigan, Ann Arbor, MI.

Leonard, J., \& Martin, D. B. (Eds.). (2013). The brilliance of Black children in mathematics: Beyond the numbers and toward new discourse. Charlotte, NC: Information Age Publishing.

Martin, D. B. (2015). The collective Black and principles to actions. Journal of Urban Mathematics Education, 8(1), 17-23.

McCrory, R., Floden, R., Ferrini-Mundy, J., Reckase, M. D., \& Senk, S. L. (2012). Knowledge of algebra for teaching: A framework of knowledge and practices. Journal for Research in Mathematics Education, 43(5), 584-615.

National Mathematics Advisory Panel. (2008). Foundations for success: The final report of the national mathematics advisory panel, U.S. Department of Education: Washington, DC.

Nasir, N. (2016). Why should mathematics educators care about race and culture? Journal of Urban Mathematics Education, 9(1), 7-18.

Nasir, N., Shah, N., Snyder, C., \& Ross, K. (2012). Stereotypes, storylines, and the learning process. Human Development, 55(5-6), 285-301.

Noel, B. (2014). Practices for teaching across differences. Unpublished manuscript. University of Michigan, Ann Arbor, MI.

Rowland, T. (2013). The knowledge quartet: The genesis and application of a framework for analysing mathematics teaching and deepening teachers' mathematics knowledge. Sisyphus-Journal of Education, 1(3), 15-43. 
Rowland, T., Huckstep, P., \& Thwaites, A. (2005). Elementary teachers' mathematics subject knowledge: The knowledge quartet and the case of Naomi. Journal of Mathematics Teacher Education, 8(3), 255-281.

Saderholm, J., Ronau, R., Brown, E. T., \& Collins, G. (2010). Validation of the Diagnostic Teacher Assessment of Mathematics and Science (DTAMS) instrument. School Science and Mathematics, 110(4), 180-192.

Senk, S. L., Tatto, M. T., Reckase, M., Rowley, G., Peck, R., \& Bankov, K. (2012). Knowledge of future primary teachers for teaching mathematics: An international comparative study. ZDM Mathematics Education, 44(3), 307-324.

Sfard, A. (2007). When the rules of discourse change, but nobody tells you: Making sense of mathematics learning from a commognitive standpoint. The Journal of the Learning Sciences, $16(4), 565-613$.

Sherin, M. G., Jacobs, V. R., \& Philipp, R. A. (Eds.). (2011). Mathematics teacher noticing: Seeing through teachers' eyes. New York: Routledge.

Shulman, L. S. (1986). Those who understand: Knowledge growth in teaching. Educational Researcher, 15(2), 4-14.

Shulman, L. S. (1987). Knowledge and teaching: Foundations of the new reform. Harvard Educational Review, 57(1), 1-23.

Silverman, J., \& Thompson, P. W. (2008). Toward a framework for the development of mathematical knowledge for teaching. Journal of Mathematics Teacher Education, 11, 499-511.

Sleep, L. (2012). The work of steering instruction toward the mathematical point: A decomposition of teaching practice. American Educational Research Journal, 49, 935-970.

Tatto, M. T., Schwille, J., Senk, S., Ingvarson, L., Peck, R., \& Rowley, G. (2008). Teacher Education and Development Study in Mathematics (TEDS-M): Conceptual framework. East Lansing, MI: Teacher Education and Development International Study Center, College of Education, Michigan State University.

Tchoshanov, M. (2011). Relationship between teacher content knowledge, teaching practice, and student achievement in middle grades mathematics. Educational Studies in Mathematics, 76(2), 141-164.

Thompson, P. W. (1984). Content versus method. College Mathematics Journal, 15(5), 394-395.

Thompson, P. W., Carlson, M. P., \& Silverman, J. (2007). The design of tasks in support of teachers' development of coherent mathematical meanings. Journal of Mathematics Teacher Education, 10(4-6), 415-432.

Open Access Except where otherwise noted, this chapter is licensed under a Creative Commons Attribution 4.0 International License. To view a copy of this license, visit http://creativecommons. org/licenses/by/4.0/.



